DOI: http://doi.org/10.15688/nav.jvolsu.2016.1.1

UDC 902/904(470.5)

LBC 63.442.7(235.55)-41

\title{
ON SOME PECULIARITIES OF USING GIRTH CLASPS BY THE NOMADS OF THE SOUTH URAL AREA AT SCYTHIAN TIME ${ }^{1}$
}

\author{
Vladimir N. Myshkin \\ Samara State University of Social Sciences and Education, Samara, Russian Federation
}

\begin{abstract}
The article is devoted to the research of peculiarities of using girth clasps by the nomadic cattlebreeders living in the steppes of South Ural area in $6^{\text {th }}-4^{\text {th }}$ centuries BC. The analysis of location of metal parts of girth clasps in interments of horses, the quantity and content of these details in interments of people and sacrificial places proves the point about the preferable usage of girth clasps by nomads at the end of $6^{\text {th }}-4^{\text {th }}$ centuries $\mathrm{BC}$, which looked like rings, horse brasses with fixed ledge-stops being perpendicular towards the plane of clasp. The left clasp consisted of two metal parts, the right - of one part.

The presence, quantity and location of ledge-stops were caused by the purpose of details of clasps. The deviation from this rule is recorded. In the article probable variants of different types of parts of clasps are studied.
\end{abstract}

Key words: South Ural area, early Iron Age, nomads, burial mounds, horse manhood, harness, girth clasps.

УДК 902/904(470.5)

ББК 63.442.7(235.55)-41

\section{О НЕКОТОРЫХ ОСОБЕННОСТЯХ ИСПОЛЬЗОВАНИЯ ПОДПРУЖНЫХ ЗАСТЕЖЕК КОЧЕВНИКАМИ ЮЖНОГО ПРИУРАЛЬЯ В СКИФСКОЕ ВРЕМЯ ${ }^{1}$}

\author{
Владимир Николаевич Мышкин \\ Самарский государственный социально-педагогический университет, г. Самара, Российская Федерация
}

Аннотация. Статья посвящена исследованию особенностей использования подпружных застежек кочевыми скотоводами, населявшими в VI-IV вв. до н. э. степи Южного Приуралья. Анализ расположения металлических деталей подпружных застежек в погребениях коней, количество и состав этих деталей в человеческих захоронениях и жертвенных местах подтверждает выводы о преимущественном использовании кочевниками в конце VI - V в. до н. э. подпружных застежек, представляющих собой кольца, бляхи

ч чаще всего с неподвижными перпендикулярно расположенными по отношению к плоскости застежки 궁 выступами-фиксаторами. Левая застежка состояла из двух металлических частей, правая - из одной. Наличие, количество и расположение выступов-фиксаторов было обусловлено назначением деталей застежек. Фи Фиксируются отклонения от этого правила. В статье рассмотрены возможные варианты использования разнотипных деталей застежек. Во второй половине V - IV в. до н. э. кочевники Южного Приуралья начали использовать одночастные левые подпружные застежки.

Ключевые слова: Южное Приуралье, ранний железный век, кочевники, курганы, всадничество, снаряжение коней, подпружные застежки. 


\section{Введение}

Важной составной частью снаряжения коней у кочевников, населявших степи Южного Приуралья в VI-IV вв. до н. э., являлись подпружные застежки. Эти детали конской амуниции, обнаруженные в кочевнических курганах рассматриваемого времени, в большинстве своем металлические, реже - костяные. Чаще всего они выполнены в виде кольца. В ряде случаев эти предметы украшены изображением в зверином стиле, и поэтому их конфигурация имеет более сложную форму. Застежки часто снабжены неподвижными выступами-фиксаторами, которые в археологической литературе назначают также штифтами, лапками, кнопками, язычками, а также петлями. Выступы-фиксаторы располагаются на одной или обеих сторонах. Известны также экземпляры, не имеющие таких выступов.

Появление подпружных застежек (или пряжек) было обусловлено необходимостью максимально удобной и надежной фиксации седла на спине лошади [Степанова, 2005, с. 109].

Начало изучения этой категории находок, происходящих из курганов кочевников Поволжья и Южного Приуралья, можно связать с работой К.Ф. Смирнова, посвященной вооружению савроматов [Смирнов, 1961]. В этой монографии исследователь определил некоторые известные в то время предметы конского снаряжения как части седельного комплекта, которые служили для скрепления подпружных и нагрудного ремней [Смирнов, 1961 , с. $88-89,96-97$, рис. $49,1-3 ; 57,1-4]$. Автором был очерчен круг аналогий таким предметам и определено время их использования кочевниками поволжских и южноуральских степей. Рассматривать вопрос о том, как именно использовались такие изделия для застегивания подпружных ремней, К.Ф. Смирнов не стал, ограничившись ссылкой на реконструкцию седла из Первого Пазырыкского кургана [Смирнов, 1961, с. 88-89, 96-97]. Очевидной причиной являлось отсутствие достаточного количества исходных данных для реконструкции способов застегивания подпруги, существовавших у скотоводов волгоуральских степей в савроматское время. Что касается седла из Первого Пазырыкского кургана, то на рисунке, опубликованном
М.П. Грязновым [Грязнов, 1950, с. 58, рис. 22], отчетливо показана только левая часть подпруги. Согласно предложенной реконструкции (рис. 1,2), кольцо крепилось на левом конце нижнего подпружного ремня, в него продевался конец верхнего подпружного ремня (приструги), который потом подтягивался наверх и завязывался.

В большинстве изданных позднее монографий и статей подпружные застежки фигурировали как часть публикуемых и анализируемых материалов [Смирнов, Петренко, 1963, с. 29-31, табл. 17, 21; Смирнов, 1964 , рис. $21,1 n, 1 \partial, 26-26 ; 27,4-6,13-14 ; 28,6,10-$ 12,14-16; Смирнов, 1975, с. 32-33, 35, 83, 84; Смирнов, 1977 , с. 26 , рис. 12,2 ; Смирнов, 1981 , с. 74, рис. 4,4-7; Мошкова, 1962, с. 211, $223-$ 224 , рис. $6,8,9 e ; 4,8$; Мошкова, 1972, рис. 3,VI; 5,6; Кадырбаев, Курманкулов, 1976, с. 141-143, 146, рис. 2,1-3; 3,4; 6,9; Кадырбаев, Курманкулов, 1977 , с. 104,105 , рис. $2,5,7 ; 4,1-2$; Кадырбаев, 1984, с. 89-91, рис. 5,1,2; Кузнецова, Курманкулов, 1993, рис. 3,8,11,13; Пшеничнюк, 1983, с. 44, табл. ХХХІІІ, 18; Пшеничнюк, 2012 , рис. 28,5 , с. 72 ; Моргунова, Трунаева, 1993, с. 16-17, рис. $17,1,2$; Железчиков, Клепиков, Сергацков, 2006, с. 33-34, рис. 73,26,22,2d; Гуцалов, 2004а, табл. 7, 18, 42; Гуцалов, 2004б, рис. 5,8 ; Гуцалов, 2009 a, с. 75 , рис. $4,1,3,4$; Гуцалов, 2009б, с. 311-312, рис. 7,7; Гуцалов, 2010, c. 62 , рис. 5,15 ; Гуцалов, 2011 , с. 83,87 , рис. $1,16-19 ; 5,6$; Яблонский, 2013, с. 75, № 66]. Особенности использования колец, пряжек и блях для застегивания подпруги при этом не являлись предметом специального исследования.

Среди работ, в которых этот вопрос рассматривается, следует назвать монографию А.В. Симоненко [Симоненко, 2009]. Опираясь на материалы, полученные при раскопках пяти скелетов взнузданных и оседланных коней кургана 8 могильника Пятимары I, автор пришел к следующим выводам. Система затягивания подпруги у кочевников Южного Приуралья несколько отличалась от скифской. Отличие состояло прежде всего в том, что подпруга пристегивалась к кольцам с обеих сторон седла. Эти кольца должны были крепиться на концах ремня, который, в свою очередь, намертво пришивался поперек ленчика. С правой стороны седел из Пятимаров крепилось 
одно, с левой - два кольца. Находки и изображения скифских подпружных пряжек на левом боку коня говорят о том, что скифы затягивали подпругу слева. Наличие же на пятимарских седлах пряжек с обеих сторон не исключает возможности регулирования подпруги как справа, так и слева. На всех рассматриваемых пряжках с внешней полукруглой стороны рамки имелся шпенек-кнопка, с внутренней (плоской) Т-образной лапкой. А.В. Симоненко предположил, что справа подпруга продевалась в кольцо, намертво пришитое к ленчику, и застегивалась на Т-образную лапку и затем для большей надежности на шпенек. Слева, охватив грудную клетку коня, подпруга должна была аналогично крепиться к двум кольцам, также намертво пришитым к ленчику. Наличие двух колец на левом боку животного, по мнению автора, могло объясняться тем, что подпруга раздваивалась на конце (рис. 1,3 ), либо тем, что кочевники использовали две подпруги. Большие литые бляхи с ажурным изображением дерущихся верблюдов, найденные около коня, по мнению исследователя, заклепкой крепились к ленчику, а подпруга застегивалась на шпеньки в нижней части бляхи. Это делало крепление очень ненадежным и говорит о том, что бляхи скорее всего были погребальными вотивами [Симоненко, 2009, c. 225-227].

Подпружным пряжкам как части конского снаряжения кочевников Южного Приуралья в скифское время посвящен один из разделов монографического исследования М.А. Очир-Горяевой [Очир-Горяева, 2012]. Существенное место в рамках этого раздела отведено системе использования подпружных застежек, существовавшей у кочевников Южного Приуралья. При анализе южноуральских материалов М.А. Очир-Горяева опиралась на результаты исследования седельных наборов пазырыкской культуры, выполненного Е.В. Степановой [Степанова, 2005; 2006]. По данным М.А. Очир-Горяевой, для застегивания подпруги кочевники Южного Приуралья использовали преимущественно три металлических детали подпружных застежек. На правой стороне лошади располагалось кольцо с двумя штифтами на внутренней стороне. На один из штифтов крепился ремень приструги, на другой - начало подпруги. Две другие детали под- пружной застежки располагались на левом боку коня. Кольца, имеющие один штифт на внутренней стороне, играли роль петли двухчастной застежки. Через нее продевался ремень приструги. Кольца, имеющие штифт на внутренней стороне и кнопку на внешней стороне, являлись пряжками. Пряжка при помощи штифта на внутренней стороне крепилась на ремень приструги. Конец приструги продевался в кольцо-петлю, натягивался и закреплялся на кнопке. Об этом свидетельствует расположение застежек возле коней в кургане 8 могильника Пятимары I [Очир-Горяева, 2012, с. 269]. Крепление пряжки с выступомкнопкой на внешней стороне на приструге подтверждает местоположение кнопки в нижней части блях с зооморфными изображениями. Крепление пряжек к ремню подпруги кнопкой вверх неизбежно ведет к расположению изображения в перевернутом виде [Очир-Горяева, 2012, с. 264, 269]. В работе М.А. ОчирГоряевой упоминаются иные сочетания различных металлических деталей подпружных застежек в составе седельных наборов. Были отмечены сочетаемость правой застежки и левой пряжки с кольцами или полукольцами, выполнявшими функцию петли, а также возможность использования кожаных петель [Очир-Горяева, 2012, с. 264, 269]. Подробно вариативность в использовании разнотипных металлических деталей подпружных застежек и степень распространенности сочетаний, отличающихся от стандартного набора, автором не рассматривалась.

Различия реконструкций системы застегивания подпруги у кочевников скифского времени на Южном Урале, предложенные в указанных выше монографиях, а также определенная лаконичность изложения ряда моментов, связанных с использованием подпружных застежек, позволяют вновь обратиться к данной теме. Ее актуальность определяется также тем, что сравнительно недавние исследования курганов в южноуральских степях позволили получить новые интересные данные о конском снаряжении.

В настоящей статье предполагается рассмотреть количество и расположение деталей подпружных застежек в захоронениях коней, а также состав седельных наборов в сопровождающем наборе вещей погребенных ко- 
чевников. Предполагается также уточнить назначение рассматриваемых принадлежностей сбруи, определить степень распространенности того или иного вида подпружных застежек, вариативность состава седельного набора.

Для исследования амуниции коней из курганов кочевников Южного Приуралья, безусловно, важны результаты анализа находок конского снаряжения из курганов ранних кочевников Алтая. Во многом это обусловлено сохранностью кожаных и деревянных частей сбруйных принадлежностей. Найденные на Алтае в погребениях коней VII-III вв. до н. э. детали амуниции позволяют реконструировать подпружные застежки скифского времени. Среди относительно недавних публикаций следует выделить важные для исследования данной проблемы работы Е.В. Степановой [Степанова 2005; 2006] и П.И. Шульги [Шульга, 2008].

В работах Е.В. Степановой система затягивания подпруг и использования подпружных застежек, существовавшая у кочевников Алтая в VII-III вв. до н. э., реконструирована следующим образом. «Скифские» седла имели только одну подпругу, которая подтягивалась слева. Подпруги пристегивались к свободным концам ремней, закрепленным поверх и поперек седельных подушек, - пристругам по терминологии, использованной Е.В. Степановой [Степанова, 2005, с. 109]. Справа подпруга пристегивалась к приструге с помощью застежки «пуговичного» типа. Поиск способов надежной фиксации седел привел к появлению двух вариантов левых подпружных застежек. Одна из них - двухчастная застежка. Этот вариант предполагал использование пряжки с носиком-кнопкой или крючком, загнутым внутрь, и бронзовой, костяной или кожаной петли, выполнявшей роль блока. Пряжка с носиком-кнопкой крепилась на подпруге. Конец подпруги продевался сквозь петлю, закрепленную на приструге, натягивался и фиксировался с помощью носика-кнопки (рис. 1,4). Одночастная застежка (рис. 1,6) состояла только из пряжки с носиком-кнопкой, выступом или крючком, отогнутыми наружу. В качестве блока выступала рамка пряжки. В этом случае пряжка закреплялась на приструге, а ремень подпруги продевался в отверстие рамки и фиксировался с помощью ото- гнутого наружу выступа пряжки [Степанова, 2005, c. 109-110].

В работах П.И. Шульги система расположения пряжек и блоков на подпружных ремнях коней, применявшаяся населением Алтая, реконструирована иначе. В раннескифское и пазырыкское время кочевники этого региона фиксировали седло двумя подпружными ремнями - широким верхним (пристругой - по терминологии, использованной Е.В. Степановой) и узким нижним [Шульга, 2008, с. 34]. Однако слева пряжка, по мнению исследователя, крепилась не к нижней подпруге, как это представлено в реконструкции Е.В. Степановой, а к широкому верхнему ремню (приструге) и располагалась здесь выступом (носиком-кнопкой, крючком) вниз. Блок (петля) из бронзы, рога или кожи размещался на левом конце узкого нижнего подпружного ремня (рис. 1,5$)$. При затягивании подпруги узкий ремешок на левом конце широкого верхнего подпружного ремня пропускался в большое отверстие блока, закрепленного на конце нижнего подпружного ремня, и застегивался на шпенек пряжки [Шульга, 2008, с. 34, 42]. На левом же конце подпружного верхнего ремня кочевники, возводившие Пазырыкские курганы и другие относительно поздние погребальные памятники, продолжали размещать использовавшиеся без блоков пряжки [Шульга, 2008 , с. 38]. На правом конце верхнего подпружного ремня (приструги) имелось отверстие, иногда их было два, для пристегивания или привязывания нижнего подпружного ремня [Шульга, 2008, с. 39]. В раннескифское время на правом конце нижнего подпружного ремня по центру располагалась небольшая продольная прорезь под застежку. В раннепазырыкской сбруе в этом месте подруги отверстий не было [Шульга, 2008, с. 42]. Способ застегивания подпружных ремней на правом боку лошади в раннескифское время был установлен по материалам из могилы 16 в могильнике Гилево-10. В этом погребении на остатках седла хорошо сохранился фрагмент кожаного верхнего правостороннего подпружного ремня шириной 5-6 см и отходящего от него тонкого узкого ремня нижней подпруги шириной $1,5-2$ см. Нижний ремень крепился к верхнему при помощи крупной бляхи диаметром 5,5 см с уплощенной запонковидной застежкой. Оба ремня 
на концах имели продольные разрезы, посредством которых надевались на шпенек следующим образом: сначала шпенек бляхи вставлялся снаружи в прорезь широкого верхнего подпружного ремня, а затем в прорезь нижнего подпружного ремня [Шульга, 2008, с. 43]. На Алтае существовал еще один способ застегивания подпружных ремней, предполагающий использование «пряжек» без выступов и предположительно выявленный в одном из курганов могильника Чесноково-1. В данном случае ремень верхнего подпружного ремня, на котором было закреплено одно кольцо, пропускался сквозь петлю блока, затем поднимался к верхнему кольцу и там, вероятно, фиксировался [Шульга, 2008, с. 35].

Следует обратить внимание на тот факт, что выводы П.И. Шульги о местоположении пряжки и петли на левом конце подпружных ремней конской амуниции кочевого населения Алтая в скифское время совпадают с выводами М.А. Очир-Горяевой о том, как в этот же период застегивалась подпруга у кочевников Южного Приуралья.

Теперь рассмотрим с учетом новых опубликованных данных количество и характер расположения деталей подпружных застежек в погребениях коней, обнаруженных в кочевнических курганах скифского времени на территории степей Южного Приуралья ${ }^{2}$.

\section{Количество и местонахождение} подпружных застежек около коней

\section{в курганах кочевников Южного Приуралья}

Данные об использовании металлических подпружных застежек, их количестве и расположении получены при исследовании погребений 10 коней. Представляется необходимым кратко охарактеризовать некоторые обрядовые особенности погребения коней, характерные для культуры южноуральских номадов. Эти черты были отмечены в ряде исследований [Очир-Горяева, 1987, с. 41; Мышкин, 1993, с. 15; Мышкин, 2012, с. 82-86; Савельев, 2000, с. 46; Гуцалов, 2007, с. 86]. В курганах, датированных концом VI - V в. до н. э., этих животных чаще всего размещали на древней поверхности южнее центрального человеческого погребения. Коней в снаряжении ук- ладывали на живот с подогнутыми ногами головой на север [Мышкин, 2012, с. 84]. Несколько иначе совершались обрядовые действия с конем в более позднее время при возведении курганов 3, 4, 6, 10 могильника Филипповский I. Дата этих погребальных комплексов приходится на вторую половину $\mathrm{V}$ IV в. до н. э. [Пшеничнюк, 2012, с. 84; Яблонский, 2008, с. 173]. Коней в этих курганах также хоронили на древней поверхности в южном секторе кургана, к югу от центральной могилы и головой по направлению к ней или в могиле. Однако принадлежности снаряжения размещали отдельно от лошадей - на надмогильном сооружении или на небольшом удалении от голов животных [Мышкин, 2012, c. 86]. Все рассмотренные далее курганы, содержащие конские погребения, датированы временем в пределах второй половины VI $\mathrm{V}$ в. до н. э. (см. табл. 1). Поэтому получить в достаточной степени достоверные сведения о характере использования металлических подпружных застежек представляется возможным только для этого периода.

Для лучшего понимания характера использования подпружных застежек следует акцентировать внимание на двух обстоятельствах. Во-первых, коней чаще всего хоронили в снаряжении. Во-вторых, животных укладывали на живот. В таком случае подпружные застежки располагались выше уровня, на котором лежал конь. Впоследствии при разрушении подпружных ремней металлические застежки должны были опускаться вниз. Их расположение при этом фиксировало взаиморасположение на подпружном ремне. Обратимся теперь к погребениям коней.

1. Могильник Пятимары I, курган 8. Обнаружено захоронение пяти животных в полном снаряжении.

Конь 1. В районе черепа обнаружены детали узды. У боков лежали 3 бронзовых кольца - одно справа и два слева. «Кольцо справа обращено выпуклой наружной стороной кверху, кольца слева лежали рядом, причем кольцо с пуговкой - наружной стороной кверху, а лапкой вниз, пуговка обращена к западу; второе кольцо, лежащее с северной стороны первого кольца, обращено внутренней стороной с выступом-лапкой кверху» [Смирнов, 1975, с. 3132]. В приведенном описании не указано, что 
кольцо у правого бока имело какие-либо выступы [Смирнов, 1975, с. 31-32], не видно их и на иллюстрации [Смирнов, 1964, рис. 27,4]. Если это так, то подпружные ремни на правом боку должны были привязываться к этому кольцу. Застежка на левом боку состояла из двух частей. Пряжка - кольцо с выступом-лапкой на внутренней стороне и кнопкой на внешней - крепилась кнопкой вниз на приструге. Именно из такого положения она могла после разрушения ремня опуститься вниз и лечь внешней стороной наверх, а кнопкой на запад то есть в сторону от коня; крепление же ее на конце подпруги кнопкой вниз не имеет смысла. В таком случае второе кольцо с одним выступом-лапкой на внутренней стороне должно было с помощью этого выступа крепиться на конце подпруги и, соответственно, располагаться ниже. Оно являлось петлей, служившей блоком. Через него продевался конец приструги, который потом поднимался наверх, натягивался и фиксировался на кнопке выше расположенной пряжки.

Конь 2. Около головы также обнаружены металлические детали узды, по бокам в районе ребер - желобчатые железные кольца. У правого бока было найдено одно кольцо, располагавшееся внутренней желобчатой стороной кверху. У левого бока под концами ребер лошади покоились один на другом два кольца. Нижнее кольцо лежало желобчатой внутренней стороной кверху, верхнее располагалось кверху выпуклой внешней стороной. На внешней и внутренней сторонах всех колец выступы отсутствовали [Смирнов, 1964, рис. 27,1,13-14; Смирнов, 1975, с. 32]. Таким образом, у этого коня подпругу и пристругу справа привязывали к одному кольцу. Левая застежка являлась двухчастной, в данном случае в качестве пряжки и петли использовались желобчатые кольца без выступов. Ремни к ним, очевидно, привязывались.

Конь 3. Около него, помимо деталей узды у головы, были обнаружены три бляхи, располагавшиеся у обоих боков. Все бляхи украшены сценой борьбы двух верблюдов. Одна бляха с выступом-лапкой на внутренней стороне находилась у правого бока. Она лежала лицевой стороной вниз, а выступом-лапкой кверху. Две бляхи располагались слева от коня и лежали одна на другой [Смирнов, 1964, рис. 27,1;
Смирнов, 1975, с. 32-33]. В данном случае следует отметить использование бляхи с одним выступом на внутренней стороне в качестве правой застежки. Две бляхи у левого бока располагались на подпружных ремнях одна выше другой и крепились одна к подпруге, другая к приструге. Одна из них имеет выступ-пуговку на внешней стороне и выступ-лапку на внутренней [Смирнов, Петренко, 1963, табл. 21,6; Смирнов, 1964, рис. 28,6 ; Смирнов, 1975 , с. 32 33]. Можно предположить, что она использовалась как пряжка двухчастной застежки, располагалась выше и крепилась к приструге.

Конь 4. Около его головы были обнаружены детали уздечного набора, около боков бронзовые кольца, лежавшие плашмя у краев ребер. Одно находилось справа, два располагались слева. Кольцо у правого бока имело две лапки на внутренней стороне, оно лежало внешней стороной кверху. Выступы на внутренней стороне располагались вдоль ребер коня [Смирнов, 1964, рис. 27,1; 28,7-12; Смирнов, 1975, с. 33]. Судя по отмеченному расположению штифтов, один из них крепился к приструге, второй - к подпруге. У левого бока, ближе к ребрам, находилось кольцо с пуговкой, обращенной кверху и к западу, а лапка на обороте - к ребрам и к востоку. Второе кольцо с лапкой на обороте вплотную примыкало к первому кольцу с западной стороны, внешней стороной было обращено вверх, лапкой к западу, то есть в сторону от коня [Смирнов, 1964, рис. 27,1; 28,7-12; Смирнов, 1975, с. 33]. Таким образом, на левом боку коня пряжка с копкой-фиксатором и лапкой на внутренней стороне располагалась выше и крепилась кнопкой вниз. Поэтому после разрушения ремней она опустилась вниз и легла кнопкой кверху и к западу (то есть в сторону от коня). Другое кольцо (то есть петля) на боку коня находилось ниже, лапкой оно крепилось к подпруге. В процессе разрушения ремней оно оказалось западнее пряжки и лежало лапкой к западу, то есть в сторону от коня.

Конь 5. Около головы также располагались детали узды, а у краев ребер плашмя лежали три бронзовых кольца: одно у правого бока и два - у левого. Кольцо с двумя лапками, обращенными вниз, лежало у конца ребер правого бока. У левого бока одно кольцо частично налегало на другое. Верхнее кольцо с 
кнопкой на наружной стороне и лапкой на внутренней было обращено кнопкой кверху и северо-западу, то есть в сторону от коня, лапкой на внутренней стороне - к ребрам. Нижнее кольцо лежало наружной стороной вниз, а единственный выступ, заменяющий лапку на внутренней стороне кольца, обращен к востоку, то есть к ребрам [Смирнов, 1964, рис. 27,1; 28,13-23; Смирнов, 1975, с. 33, 35]. Детали левой двучастной подпружной застежки около коня 5 распределены точно так же, как и у коня 4. Единственное отличие, зафиксированное при раскопках, - левая петля, опустившись вниз при разрушении ремней, легла внутренней стороной вверх, и поэтому имеющаяся у нее лапка была обращена к ребрам коня.

\section{2. Могильник Пятимары I, курган 6.} Обнаружено погребение одного коня. Около головы были найдены детали уздечного набора. Однако металлические подпружные застежки около боков отсутствовали [Смирнов, 1964, рис. 29,4a-4d; Смирнов, 1975, с. 27]. Обычай погребения коней в полном снаряжении, характерный для кочевников Южного Приуралья, и наличие деталей узды около головы позволяет предположить, что конь был погребен оседланным, а седло фиксировалось с помощью ременных петель и/или деревянных застежек ${ }^{3}$.

3. Могильник Кырык-Оба II, курган 19. Исследовано погребение одного коня. У правой стороны конского скелета в районе ребер лежало железное кольцо, не имеющее выступов и покрытое золотой фольгой [Гуцалов, 2010 , с. 62 , рис. 5,15$]$. Подпруга и приструга к кольцу, очевидно, привязывались. Слева они могли скрепляться ременными петлями и/или деревянными застежками.

4. Могильник Кырык-Оба II, курган 16. Выявлено погребение одного коня. В районе его ребер найдено массивное бронзовое кольцо (рис. 5,6) с двумя лапками на внутренней стороне [Сдыков М.Н. и др., 2007, c. 81; Гуцалов, 2011, с. 87]. Из публикаций неясно, у какого бока животного и как располагалось кольцо.

5. Могильник Лебедевка II, курган 9. Погребение одного коня. Около головы найдены металлические детали узды. Возле ребер обнаружены бронзовые «подпружные кольца» [Гуцалов, 2009б, с. 311]. Подроб- ное описание их расположения не приводится. Одно из колец имеет кнопку на внешней стороне и выступ-лапку на внутренней, втоpoe - один выступ на внутренней стороне. Эти находки можно рассматривать соответственно как пряжку и петлю двухчастной подпружной застежки.

6. Могильник Илекшар I, курган 1. Обнаружены скелеты двух коней. Возле голов животных располагались детали узды. В районе нижней части ребер «среди кожаных ремней лежали бронзовые... бляхи, выполненные в скифском зверином стиле: две одинарные, представленные фигурками кошачьего хищника, и две тройчатые, на которых изображена сцена терзания хищниками кошачьей породы копытного животного (косули?)» [Гуцалов, 2009a, с. 75 , рис. 3,4,A1-9]. Всего были найдены четыре металлические детали подпружных застежек, однако краткое описание и иллюстрации не дают ясного представления о том, сколько блях и какие из них являлись частью амуниции каждого из коней. Судя по выступу-крючку на внешней стороне одной из «тройчатых» блях и боковому выступу на одной из блях в виде лежащего хищника, это были пряжки.

7. Могильник Три Мара, курган 3. Около скелета коня в этом кургане, помимо принадлежностей уздечного набора, найденных около головы животного, обнаружены пять бронзовых деталей седельного комплекта. Они располагались около боков коня. Бляха с правого бока лежала лапками вверх, бляха с левого бока - лапками вниз [Смирнов, 1981, c. 74]. В публикации не указано, какая из двух блях с лапками на внутренней стороне [Смирнов, 1981 , рис. $4,4,5]$ располагалась у правого бока лошади, какая - у левого. Положение еще одной бляхи, украшенной изображением четырех голов грифонов [Смирнов, 1981, рис. 4,6], не установлено, так как она в процессе снятия насыпи была сдвинута ножом бульдозера [Смирнов, 1981, с. 74]. Одна из блях, обнаруженная около ребер лошади, имеет два выступа-лапки на внутренней стороне и кнопку-фиксатор - на внешней. Ее следует рассматривать как пряжку левой двухчастной подпружной застежки. Учитывая местонахождение блях и колец с выступом-кнопкой на внешней стороне возле коней 4 и 5 в кургане 8 
могильника Пятимары I, можно предположить, что данная бляха крепилась на приструге изображениями голов грифонов вверх с помощью двух выступов-лапок на внутренней стороне (рис. 2,2). В таком случае бляху, сдвинутую бульдозером [Смирнов, 1981, рис. 4,6], можно рассматривать как петлю этой застежки. Петля должна была крепиться с помощью двух штифтов (выступов-лапок) на конце подпруги (рис. 2,2). Бляха с изображением двух противопоставленных голов грифонов, имеющая два выступа на внутренней стороне, вероятно, являлась правой застежкой. В этом случае она крепилась на приструге с помощью обоих выступов.

Два кольца, одно из которых найдено около передней части грудной клетки, могли использоваться, судя по их расположению, для крепления нагрудника к пристругам. О возможности такого использования колец свидетельствует наличие детали, скрепляющей нагрудник и ремень седла в составе снаряжения коня, изображенного на ковре (рис. 1,1$)$ из 5-го Пазырыкского кургана [Руденко, 1960, рис. $152, ж]$.

Итак, по имеющейся в археологической литературе информации, использование трех металлических деталей для затягивания подпруги зафиксировано у 5 коней. Все эти случаи прослежены в кургане 8 могильника Пятимары I (табл. 2). При этом одна из деталей располагалась у правого бока коня, а две другие, являясь двухчастной застежкой, - у левого бока. Есть основания полагать, что таким же образом располагались застежки в погребении коня в кургане 3 могильника Три Мара. Система крепления подпруги у этого животного была дополнена металлическими кольцами для крепления нагрудника к приструге. Использование двух металлических застежек зафиксировано около одного коня. Применение одной металлической застежки для застегивания подпруги отмечено при исследовании двух коней. В одном случае в кургане 6 могильника Пятимары I [Смирнов, 1975, c. 27] возле коня лежали детали узды, но отсутствовали подпружные застежки (табл. 2). Учитывая традицию кочевников Южного Приуралья этого времени хоронить лошадей в полном снаряжении [Мышкин, 2012, с. 82-86], нельзя исключать, что в данном случае конь был также погребен оседланным, но застежки не были металлическими и поэтому не сохранились.

Для понимания функции тех или иных металлических деталей седельного набора целесообразно рассмотреть местоположение колец и блях с различающимся количеством и расположением выступов у боков погребенных коней. В этом случае можно опереться пока только на данные, полученные при раскопках кургана 8 могильника Пятимары I. Металлические кольца без выступов-лапок на внутренней стороне и кнопок на внешней, в тех случаях, когда указано их местоположение, располагались как у правого бока коней в одном экземпляре, так и у левого бока вместе с другой деталью, как правило, пряжкой (табл. 2). В первом случае ремни подпруги и приструги ${ }^{4}$ могли крепиться по-разному: один из них намертво, другой - привязываться. Во втором случае такие кольца использовались как элементы двухчастной левой подпружной застежки. В амуниции коня из кургана 3 могильника Три Мара такие кольца использовались, по всей видимости, для соединения седла с нагрудником.

Кольца и бляхи с одним выступом на внутренней стороне чаще располагались вместе с другой деталью застежки у левого бока коней, размещаясь ниже последней или дальше от бока животного. Из этого следует, что они являлись петлями левой двухчастной застежки и крепились к подпруге (нижнему подпружному ремню). Следует особо отметить, что некоторые бляхи в виде фигур животных с одним или двумя выступами-лапками на обратной стороне имеют в верхней части выделенную дужку для продевания ремня приструги (рис. 2,3). Такие бляхи обнаружены в погребении 1 кургана 1 могильника Сынтас 1 [Кадырбаев, Курманкулов, 1976, рис. 2,1], курганах 5 и 9 могильника Бес-Оба [Кузнецова, Курманкулов, 1993, рис. 3,9,11; Кадырбаев, 1984 , рис. 5,1]. У правого бока коня бляха с одним выступом-лапкой располагалась в одном случае и служила, по всей видимости, правой застежкой (табл. 2).

Кольца и бляхи с двумя выступами на внутренней стороне, в тех случаях, когда их местоположение указано, лежали у правого бока коня и играли роль правой застежки. Рас- 
положение лапок на внутренней стороне одной из них - вдоль ребер коня - свидетельствует о том, что одна из лапок могла крепиться к приструге, другая - к подпруге. Не исключено, что ремни приструги и подпруги крепились одновременно на обе лапки.

Кольца и бляхи с одним выступом-лапкой на обратной стороне и выступом-кнопкой на внешней стороне всегда располагались у левого бока животного (табл. 2), являясь пряжками двухчастной застежки. Пряжка с помощью лапки крепилась к приструге таким образом, чтобы внешний выступ-кнопка был направлен к концу ремня, то есть вниз. При затягивании конец приструги продевался сквозь кольцо петли или дужку на бляхе, закрепленной на подпружном ремне, натягивался и фиксировался на кнопке пряжки (рис. 2,13). В качестве левой двухчастной застежки могли также использоваться два кольца. Одно кольцо выполняло функцию пряжки и крепилось на приструге, второе служило петлей и крепилось (привязывалось, пришивалось) на конце подпруги. В этом случае конец приструги продевался сквозь нижнее кольцо, натягивался и привязывался к верхнему кольцу.

\section{Количество подпружных застежек в составе погребального инвентаря людей и жертвенных местах в курганах Южного Приуралья}

Рассмотрим количество деталей металлических подпружных застежек в составе сопровождающего инвентаря погребенных кочевников и жертвенных местах. Оно может быть различным. В одиннадцати комплексах со сбруей были найдены три детали металлических подпружных застежек $(47,8 \%)$, две детали обнаружены в 5 комплексах $(21,7$ \%), одна деталь встречена в 5 комплексах $(21,7 \%)^{5}$. Редко встречаются четыре или пять металлических деталей седельного набора (табл. 1). В тех случаях, когда в курганах и погребениях встречаются три металлические детали подпружных застежек, они, как уже отмечала М.А. Очир-Горяева [Очир-Горяева, 2012, с. 264-265], представляют собой практически стандартный набор. Этот набор состоит из кольца (бляхи) с двумя выступами-лапками на внутренней стороне; пряжки с одним, редко двумя, выступом-лапкой на внутренней стороне и петли в виде кольца или бляхи с одним выступом (изредка лапок две) на внутренней стороне.

В жертвенном комплексе кургана 4 могильника Филипповка I, датированном второй половиной V - IV в. до н. э., обнаружена костяная подпружная пряжка, имеющая две прямоугольные прорези и выступ, расположенный снаружи в одной плоскости с рамкой [Яблонский, 2008, с. 173; Яблонский, 2013, с. 73, № 66]. Следует отметить несомненное сходство филипповской находки с пряжками из кочевнических курганов Алтая [Степанова, 2006, рис. 9,1-3,5,10]. На Алтае такие пряжки использовались как одночастные застежки. В качестве блока выступала рамка пряжки. Пряжка закреплялась на приструге (рис. 1,5), а ремень подпруги продевался в отверстие рамки и фиксировался с помощью выступа пряжки [Степанова, 2005, с. 109-110]. Аналогичным образом, очевидно, использовались такие пряжки и кочевниками Южного Приуралья (рис. 2,4). Указанная находка свидетельствует, что во второй половине V - IV в. до н. э. кочевники этого региона начали использовать одночастные левые застежки, что фиксирует появление новых культурных традиций.

\section{Заключение}

Подводя итоги, необходимо выделить следующие моменты.

Судя по находкам пряжек (блях, колец) около скелетов коней в курганах и в составе сопровождающего погребального инвентаря умерших людей, кочевники Южного Урала во второй половине VI - V в. до н. э. для застегивания подпруги использовали застежки, состоящие чаще всего из трех металлических деталей. В тех случаях, когда в погребальных комплексах встречены одна или две металлических детали подпружных застежек, при застегивании подпруги, вероятно, использовались ременные петли и узлы, а также деревянные застежки.

Левая двухчастная застежка состояла из пряжки и петли. Пряжка в виде кольца или бляхи имела один выступ-лапку (редко два-три) на внутренней стороне и неподвижный фиксатор (пуговку, крючок) - на внешней. Выступ 
В.Н. Мышкин. О некоторых особенностях использования подпружных застежек кочевниками

на внутренней стороне использовался для крепления к приструге. Пряжка крепилась внешним выступом-кнопкой в сторону окончания ремня приструги (то есть вниз, если ремень спускался по боку коня). Конец приструги оставался свободным и продевался сквозь кольцо или дужку петли, прикрепленной к подпруге, потом натягивался и фиксировался на выступе-кнопке пряжки. Не исключено использование в качестве пряжки кольца, имеющего отверстие, но без выступов на внешней и внутренней сторонах. Петля, как правило, представляла собой кольцо или бляху с одним выступом (редко двумя) на внутренней стороне. В качестве петли могло использоваться также кольцо без штифтов. Некоторые бляхи, служившие петлями, имели дужки для продевания ремня, расположенные в одной плоскости со щитком. В качестве левой двухчастной застежки могли также использоваться два кольца. Одно кольцо выполняло функцию пряжки и крепилось на приструге, второе служило петлей и крепилось на конце приструги. В этом случае конец приструги продевался сквозь нижнее кольцо, натягивался и привязывался к верхнему кольцу.
Правая застежка представляет собой, как правило, кольцо или бляху с двумя выступами на внутренней стороне. В таком случае один выступ-лапка крепился к приструге, другой - к подпруге. Ремни приструги и подпруги, вероятно, могли крепиться к обеим лапкам. Реже в качестве правой застежки использовались кольца без выступов. Кольцо могло намертво прикрепляться к одному из ремней, второй ремень привязывался. Не исключено использование в качестве правой застежки колец и блях с одним или тремя выступами на внутренней стороне.

Во второй половине V - IV в. до н. э. кочевники Южного Приуралья начали использовать левые одночастные подпружные застежки из кости, что свидетельствует о появлении в этом регионе новых культурных традиций.

Наличие, количество и расположение неподвижных выступов-фиксаторов на подпружных застежках обусловлены функцией последних при застегивании подпруги. Признаки, описывающие данные характеристики застежек, необходимо учитывать при создании типологии этой группы находок. 
V.N. Myshkin. On Some Peculiarities of Using Girth Clasps by the Nomads

\section{ИЛЛЮСТРАЦИИ}

Таблииа 1

\section{Наличие и количество подпружных застежек в курганах скифского времени на территории Южного Приуралья}

\begin{tabular}{|c|c|c|c|c|}
\hline $\begin{array}{c}\text { № } \\
\text { ㅇ/ }\end{array}$ & Памятник & $\begin{array}{l}\text { Количество } \\
\text { блях, } \\
\text { пряжек или } \\
\text { колец } \\
\end{array}$ & $\begin{array}{c}\text { Дата } \\
\text { (вв. до н. э.) }\end{array}$ & Публикация \\
\hline 1 & Аландский III, к. 5 & 3 & конец VI - начало V & Мошкова, 1972, рис. $3, V I ; 5,6$, с. 61,68 \\
\hline 2 & $\begin{array}{l}\text { Альмухаметовский, } \\
\text { к. } 8 *\end{array}$ & 1 & первая половина V & $\begin{array}{l}\text { Пшеничнюк, 1983, с. 44, } \\
\text { табл. XXXIII,18; Берлизов, 2011, с. } 186\end{array}$ \\
\hline 3 & Бесоба, к. 1 * & 2 & $\begin{array}{c}\text { вторая половина VI - } \\
\text { начало V } \\
\end{array}$ & $\begin{array}{l}\text { Кадырбаев, Курманкулов, } 1977, \text { рис. } 2, \\
5,7, \text { с. } 104,114\end{array}$ \\
\hline 4 & Бесоба, к. 2 * & 2 & $\begin{array}{c}\text { вторая половина VI - } \\
\text { начало V }\end{array}$ & $\begin{array}{l}\text { Кадырбаев, Курманкулов, } 1977, \\
\text { рис. } 4,1-2, \text { с. } 105,114\end{array}$ \\
\hline 5 & Бесоба, к. 5 & 3 & конец VI - V & $\begin{array}{l}\text { Кадырбаев, 1984, с. 89, 91; Кузнецова, } \\
\text { Курманкулов, 1993, рис. } 3,8,11,13\end{array}$ \\
\hline 6 & Бесоба, к. 9 * & 3 & $\begin{array}{c}\text { вторая половина VI - } \\
\text { начало V }\end{array}$ & Кадырбаев, 1984, с. 90-91, рис. 5,1,2,6 \\
\hline 7 & Жалгызоба & $1(?)$ & конец VI - V & Гуцалов, 2004а, табл. 7,18,42 \\
\hline 8 & $\begin{array}{l}\text { Илекшар I, } \\
\text { к. } 1 \text { (кони 1-2) }\end{array}$ & 4 & $\begin{array}{c}\text { конец VI - } \\
\text { первая половина V }\end{array}$ & Гуцалов, 2009a, с. 75, рис. $4,1,3,4$ \\
\hline 9 & $\begin{array}{l}\text { Кырык-Оба II, } \\
\text { к. 2, погребение * }\end{array}$ & 3 & $\begin{array}{c}\text { конец VI - } \\
\text { первая половина V }\end{array}$ & Гуцалов, 2011, рис. 1,19, с. 83,93 \\
\hline 10 & $\begin{array}{l}\text { Кырык-Оба II, к. 2, } \\
\text { пола, жертвенное место }\end{array}$ & 3 & $\begin{array}{c}\text { конец VI - } \\
\text { первая половина V }\end{array}$ & Гуцалов, 2011, рис. 1,16-18, с. 83, 93 \\
\hline 11 & $\begin{array}{l}\text { Кырык-Оба II, } \\
\text { к. } 16 \text { (конь) }\end{array}$ & 1 & $\begin{array}{c}\text { конец VI - } \\
\text { первая половина V }\end{array}$ & Гуцалов, 2011, рис. 5,6, с. 87, 93 \\
\hline 12 & $\begin{array}{l}\text { Курык-Оба II, } \\
\text { к. } 19 \text { (конь) }\end{array}$ & 1 & $\begin{array}{c}\text { конец VI - } \\
\text { первая половина V }\end{array}$ & Гуцалов, 2010, с. 62, рис. 5,15 \\
\hline 13 & Лебедевка II, к. 9 & 2 & $\begin{array}{c}\text { конец VI - } \\
\text { первая половина V }\end{array}$ & Гуцалов, 2009б, с. 311-312, рис. 7,7 \\
\hline 14 & $\begin{array}{l}\text { Лебедевка VII, } \\
\text { к. 16, погр. } 7 \text { (скелет 3) }\end{array}$ & 3 & конец V - IV & $\begin{array}{l}\text { Железчиков, Клепиков, Сергацков, } \\
\text { 2006, с. 33-34, 38, рис. } 73,2, \sigma, 2, \partial\end{array}$ \\
\hline 15 & $\begin{array}{l}\text { Мечет-Сай, } \\
\text { к. } 2, \text { п. } 2 *\end{array}$ & 3 & $\begin{array}{c}\text { конец VI - } \\
\text { первая половина V }\end{array}$ & $\begin{array}{l}\text { Смирнов, } 1975, \text { с. } 83,90 ; 1961, \\
\text { рис. } 1-3 ; 1964, \text { рис. } 21, \ln , 1 \partial\end{array}$ \\
\hline 16 & $\begin{array}{l}\text { Мечет-Сай, } \\
\text { к. } 2, \text { п. } 3 \text { * }\end{array}$ & 2 & $\begin{array}{c}\text { конец VI - } \\
\text { первая половина V }\end{array}$ & $\begin{array}{l}\text { Смирнов, } 1975 \text {, с. } 84,90 ; 1961, \text { рис. } 4 \text {; } \\
1964, \text { рис. } 21,26-28\end{array}$ \\
\hline 17 & $\begin{array}{l}\text { Новый Кумак, } \\
\text { к. } 7, \text { п. } 1\end{array}$ & 4 & $\mathrm{~V}$ & $\begin{array}{l}\text { Мошкова, } 1962, \text { с. } 211,223-224, \\
\text { рис. } 6,8,9 e\end{array}$ \\
\hline 18 & $\begin{array}{l}\text { Новый Кумак, } \\
\text { к. } 19, \text { п. } 1\end{array}$ & 1 & рубеж VI-V & $\begin{array}{l}\text { Мошкова, } 1962, \text { с. } 221 \text {, рис. } 14,8 ; \\
\text { Смирнов, Петренко, } 1963, \text { с. } 17\end{array}$ \\
\hline 19 & $\begin{array}{l}\text { Новый Кумак, } \\
\text { к. 19, п. } 2\end{array}$ & 2 & конец VI & Смирнов, 1977, с. 26, рис. 12,2 \\
\hline 20 & Покровка II, к. 2 & 2 & конец VI - V & $\begin{array}{l}\text { Моргунова, Трунаева, 1993, с. 16-17, } \\
\text { рис. } 17,1,2\end{array}$ \\
\hline 21 & $\begin{array}{l}\text { Пятимары I, к. 8, } \\
\text { конь } 1\end{array}$ & 3 & $\begin{array}{c}\text { конец VI - начало V, } \\
\text { начало V }\end{array}$ & $\begin{array}{l}\text { Смирнов, } 1975, \text { с. } 32,35 ; 1964, \\
\text { рис. } 27,4-6, \text { с. } 50\end{array}$ \\
\hline 22 & $\begin{array}{l}\text { Пятимары I, к. 8, } \\
\text { конь } 2\end{array}$ & 3 & $\begin{array}{c}\text { конец VI - начало V, } \\
\text { начало V }\end{array}$ & $\begin{array}{l}\text { Смирнов, } 1975, \text { с. } 32,35 ; 1964, \\
\text { рис. } 27,13-14, \text { с. } 50\end{array}$ \\
\hline 23 & $\begin{array}{l}\text { Пятимары I, к. 8, } \\
\text { конь } 3\end{array}$ & 3 & $\begin{array}{c}\text { конец VI - начало V, } \\
\text { начало V }\end{array}$ & $\begin{array}{l}\text { Смирнов, } 1975, \text { с. } 32-33,35 ; 1964 \text {, } \\
\text { рис. } 28,6, \text { с. } 50\end{array}$ \\
\hline 24 & $\begin{array}{l}\text { Пятимары I, к. 8, } \\
\text { конь } 4\end{array}$ & 3 & $\begin{array}{c}\text { конец VI - начало V, } \\
\text { начало V }\end{array}$ & $\begin{array}{l}\text { Смирнов, } 1975, \text { с. } 33,35 ; 1964, \\
\text { рис. } 28,10-12, \text { с. } 50\end{array}$ \\
\hline 25 & $\begin{array}{l}\text { Пятимары I, к. 8, } \\
\text { конь } 5\end{array}$ & 3 & $\begin{array}{c}\text { конец VI - начало V, } \\
\text { начало V }\end{array}$ & $\begin{array}{l}\text { Смирнов, } 1975, \text { с. } 33,35 ; 1964 \text {, } \\
\text { рис. } 28,14-16, \text { с. } 50\end{array}$ \\
\hline 26 & $\begin{array}{l}\text { Сынтас I, к. 1, } \\
\text { погр. } 1\end{array}$ & 3 & $\begin{array}{c}\text { конец VI - } \\
\text { первая половина V }\end{array}$ & $\begin{array}{l}\text { Кадырбаев, Курманкулов, 1976, с. } 143 \text {, } \\
\text { рис. } 2,1-3 ; 1977, \text { с. } 103\end{array}$ \\
\hline 27 & $\begin{array}{l}\text { Сынтас I, к. 1, } \\
\text { погр. } 2\end{array}$ & 3 & $\begin{array}{c}\text { конец VI - } \\
\text { первая половина V }\end{array}$ & $\begin{array}{l}\text { Кадырбаев, Курманкулов, } 1976, \text { с. } 141- \\
142, \text { рис. } 3,4 ; 1977, \text { с. } 103\end{array}$ \\
\hline 28 & $\begin{array}{l}\text { Сынтас I, к. 1, } \\
\text { погр. } 3\end{array}$ & 1 & $\begin{array}{c}\text { конец VI - } \\
\text { первая половина V }\end{array}$ & $\begin{array}{l}\text { Кадырбаев, Курманкулов, 1976, с. 146, } \\
\text { рис. } 6,9 ; 1977, \text { с. } 103\end{array}$ \\
\hline 29 & $\begin{array}{l}\text { Танаберген, к. } 4, \\
\text { погр. } 1, \text { ск. } 2 *\end{array}$ & 1 & $\begin{array}{c}\text { конец VI - } \\
\text { первая половина V }\end{array}$ & Гуцалов, 2004б, рис. 5, 8, с. 148 \\
\hline
\end{tabular}


B.Н. Мышкин. О некоторых особенностях использования подпружных застежек кочевниками

Окончание таблицьь 1

\begin{tabular}{|c|c|c|c|c|}
\hline $\begin{array}{c}\text { № } \\
\Pi / \Pi\end{array}$ & Памятник & $\begin{array}{c}\text { Количество } \\
\text { блях, пря- } \\
\text { жек или } \\
\text { колец } \\
\end{array}$ & $\begin{array}{c}\text { Дата } \\
\text { (вв. до н. э.) }\end{array}$ & Публикация \\
\hline 30 & Три Мара, к. 3 (конь) & 5 & $\begin{array}{c}\text { вторая половина VI, } \\
\text { рубеж VI-V }\end{array}$ & Смирнов, 1981, с. 74,78 , рис. $4,4-7$ \\
\hline 31 & $\begin{array}{l}\text { Филипповский I, } \\
\text { к. } 1 \text { * }\end{array}$ & 2 & $\begin{array}{c}\text { начало IV; } \\
\text { вторая половина V - IV }\end{array}$ & $\begin{array}{l}\text { Пшеничнюк, } 2012, \text { рис. } 28,5, \text { с. } 72, \\
87 ; \\
\text { Яблонский, } 2008 \text {, с. } 173\end{array}$ \\
\hline 32 & $\begin{array}{l}\text { Филипповский I, } \\
\text { к. } 4, \text { жертвенный } \\
\text { комплекс }\end{array}$ & 1 & $\begin{array}{c}\text { конец V - середина IV; } \\
\text { V - середина IV }\end{array}$ & $\begin{array}{l}\text { Яблонский, 2013, с. 73, № 66; 2008, } \\
\text { с. } 173\end{array}$ \\
\hline 33 & $\begin{array}{l}\text { Черниговский, кур- } \\
\text { ган у поселка * }\end{array}$ & 3 & вторая половина VI & Смирнов, 1964 , с. $39-40$, рис. $9,1 \%$ \\
\hline
\end{tabular}

* - разрушенные погребения или жертвенные места.

Таблица 2

\section{Расположение деталей металлических подпружных застежек около коней в курганах скифского времени на территории Южного Приуралья}

\begin{tabular}{|c|c|c|c|c|c|c|c|c|c|c|c|c|c|c|}
\hline \multirow{3}{*}{$\begin{array}{l}\text { № } \\
\Pi / \Pi\end{array}$} & \multirow{3}{*}{$\begin{array}{c}\text { Наименование } \\
\text { памятника }\end{array}$} & \multirow{3}{*}{$\begin{array}{l}\text { Кол- } \\
\text { во }\end{array}$} & \multicolumn{12}{|c|}{ Расположение около бока коня } \\
\hline & & & \multicolumn{3}{|c|}{$\begin{array}{c}\text { Без выступов- } \\
\text { фиксаторов на внутрен- } \\
\text { ней или внешней } \\
\text { стороне }\end{array}$} & \multicolumn{3}{|c|}{$\begin{array}{c}\text { С одним выступом- } \\
\text { фиксатором (лапкой) } \\
\text { на внутренней сто- } \\
\text { роне }\end{array}$} & \multicolumn{3}{|c|}{$\begin{array}{c}\text { С двумя выступ ами - } \\
\text { фиксаторами (лапка- } \\
\text { ми) на внутренней } \\
\text { стороне }\end{array}$} & \multicolumn{3}{|c|}{$\begin{array}{c}\text { С одним-двумя высту- } \\
\text { пами-фиксаторами на } \\
\text { внутренней стороне } \\
\text { или без них и высту- } \\
\text { пом-фиксатором } \\
\text { (кнопкой) на внешней } \\
\text { стороне } \\
\end{array}$} \\
\hline & & & $\begin{array}{l}\text { у ле- } \\
\text { вого }\end{array}$ & $\begin{array}{l}\text { у пра- } \\
\text { вого }\end{array}$ & $\begin{array}{l}\text { не оп- } \\
\text { реде- } \\
\text { лено }\end{array}$ & $\begin{array}{c}\text { у } \\
\text { ле- } \\
\text { вого } \\
\end{array}$ & $\begin{array}{c}\text { у } \\
\text { пра- } \\
\text { вого }\end{array}$ & $\begin{array}{l}\text { не оп- } \\
\text { реде- } \\
\text { лено }\end{array}$ & $\begin{array}{l}\text { у ле- } \\
\text { вого }\end{array}$ & $\begin{array}{c}\text { у } \\
\text { пра- } \\
\text { вого }\end{array}$ & $\begin{array}{l}\text { не оп- } \\
\text { реде- } \\
\text { лено }\end{array}$ & $\begin{array}{l}\text { у ле- } \\
\text { вого }\end{array}$ & $\begin{array}{c}\text { y } \\
\text { пра- } \\
\text { вого }\end{array}$ & $\begin{array}{l}\text { не оп- } \\
\text { реде- } \\
\text { лено }\end{array}$ \\
\hline 1 & $\begin{array}{l}\text { Пятимары I, } \\
\text { курган 6, конь }\end{array}$ & - & - & - & - & - & - & - & - & - & - & - & - & - \\
\hline 2 & $\begin{array}{l}\text { Кырык-Оба II, } \\
\text { курган 19, конь }\end{array}$ & 1 & - & 1 & - & - & - & - & - & - & - & - & - & - \\
\hline 3 & $\begin{array}{l}\text { Кырык-Оба II, } \\
\text { курган 16, конь }\end{array}$ & 1 & - & - & - & - & - & - & - & - & 1 & - & - & - \\
\hline 4 & $\begin{array}{l}\text { Лебедевка II, } \\
\text { курган 9, конь }\end{array}$ & 2 & - & - & - & - & - & 1 & - & - & - & - & - & 1 \\
\hline 5 & $\begin{array}{l}\text { Илекшар I, кур- } \\
\text { ган 1, кони 1-2 }\end{array}$ & 4 & - & - & 1 & - & - & - & - & - & - & - & - & 2 \\
\hline 6 & $\begin{array}{l}\text { Пятимары I, } \\
\text { курган 8, конь } 1\end{array}$ & 3 & - & 1 & - & 1 & - & - & - & - & - & 1 & - & - \\
\hline 7 & $\begin{array}{l}\text { Пятимары I, } \\
\text { курган 8, конь } 2\end{array}$ & 3 & 2 & 1 & - & - & - & - & - & - & - & - & - & - \\
\hline 8 & $\begin{array}{l}\text { Пятимары I, } \\
\text { курган 8, конь } 3 \\
\end{array}$ & 3 & - & - & - & - & 1 & - & - & - & - & 1 & - & - \\
\hline 9 & $\begin{array}{l}\text { Пятимары I, } \\
\text { курган 8, конь } 4\end{array}$ & 3 & - & - & - & 1 & - & - & - & 1 & - & 1 & - & - \\
\hline 10 & $\begin{array}{l}\text { Пятимары I, } \\
\text { курган 8, конь } 5\end{array}$ & 3 & - & - & - & 1 & - & - & - & 1 & - & 1 & - & - \\
\hline 11 & $\begin{array}{l}\text { Три Мара, } \\
\text { курган 3, конь }\end{array}$ & 5 & - & 1 & 1 & - & - & - & - & - & 2 & - & - & 1 \\
\hline & \multirow[t]{2}{*}{$B C E \Gamma O$} & \multirow[t]{2}{*}{28} & 2 & 4 & \multirow[t]{2}{*}{2} & 3 & 1 & \multirow[t]{2}{*}{1} & - & 2 & \multirow[t]{2}{*}{3} & 4 & - & 4 \\
\hline & & & $33,3 \%$ & $66,7 \%$ & & $75 \%$ & $25 \%$ & & - & $100 \%$ & & $100 \%$ & & \\
\hline
\end{tabular}



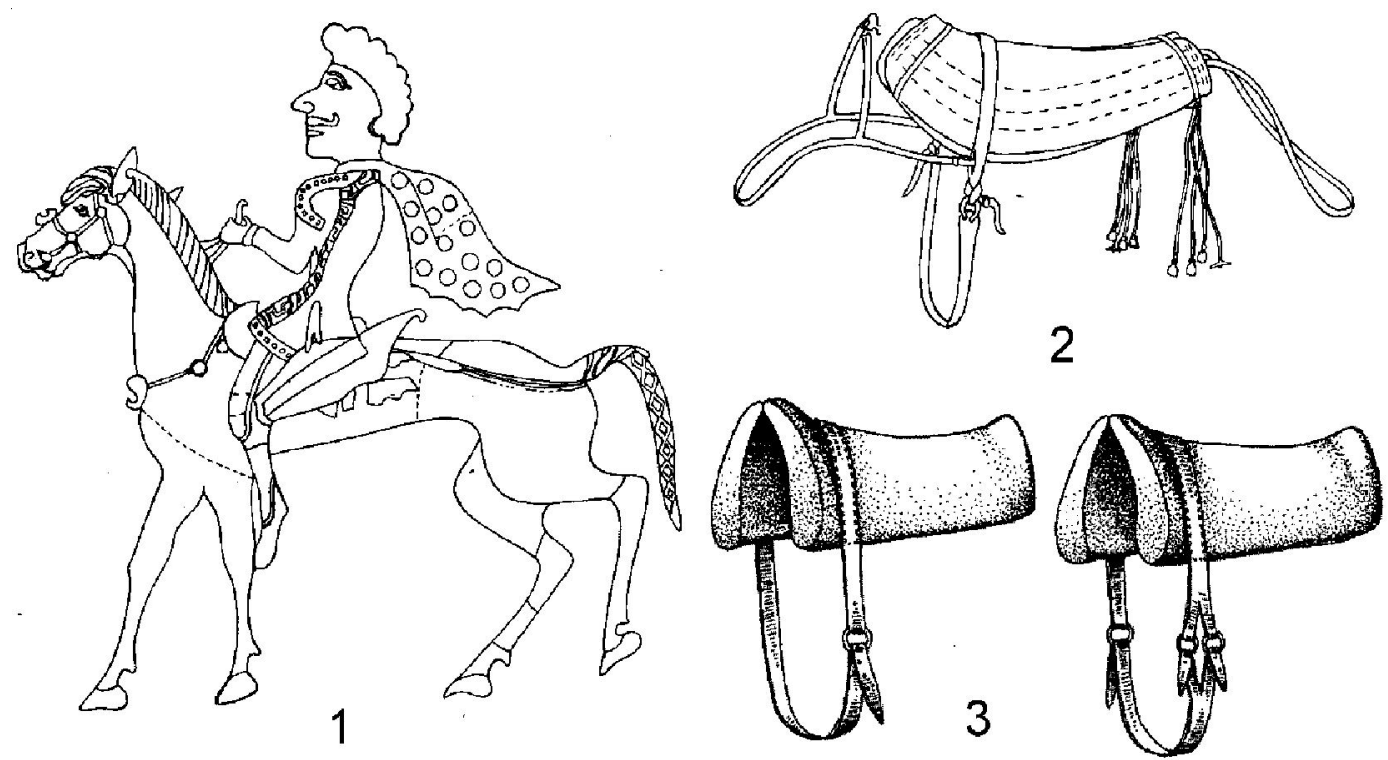

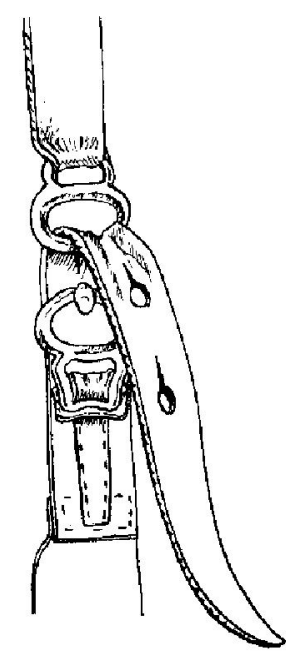

4

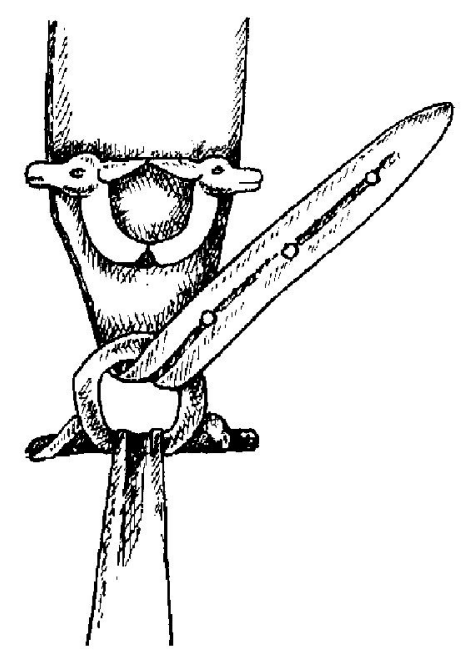

5

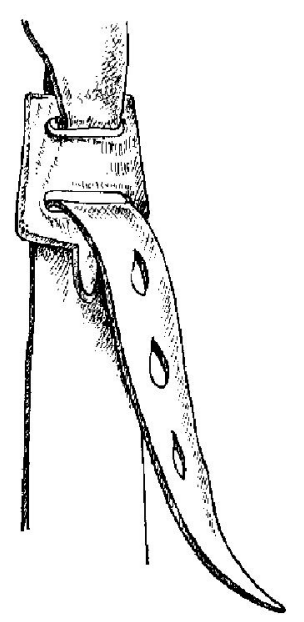

6

Рис. 1. Детали седельного набора на древних изображениях и в современных реконструкциях:

1 - изображение всадника на ковре из 5-го Пазырыкского кургана (по: [Руденко, 1960, рис. 152,ж]);

2 - седло из 1-го Пазырыкского кургана (по: [Грязнов, 1950, с. 58, рис. 22]);

3 - седла и система застегивания подпруги у кочевников Южного Приуралья.

Схема-реконструкция А.В. Симоненко (по: [Симоненко, 2009, с. 224, рис. 182]);

4 - левая двухчастная подпружная застежка из кургана 2 могильника Башадар.

Реконструкция Е.В. Степановой (по: [Степанова, 2006, с. 129, рис. 12,1]);

5 - левая двухчастная подпружная застежка по материалам могильника Гилево-10.

Реконструкция П.И. Шульги (по: [Шульга, 2013, рис. 58,II]);

6 - левая одночастная подпружная застежка из кургана 42 могильника Пазырык.

Реконструкция Е.В. Степановой (по: [Степанова, 2006, с. 129, рис. 12,4]) 
В.Н. Мышкин. О некоторых особенностях использования подпружных застежек кочевниками

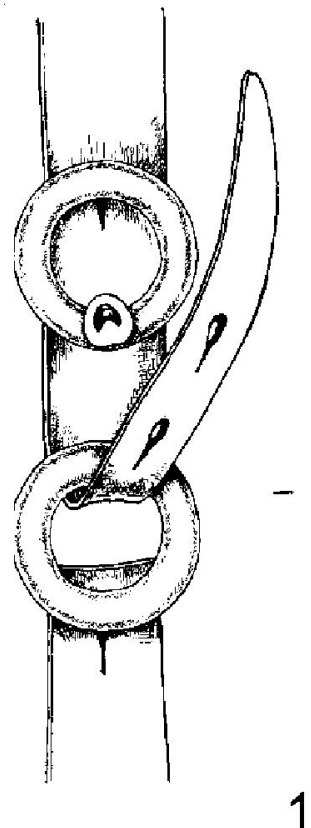

1

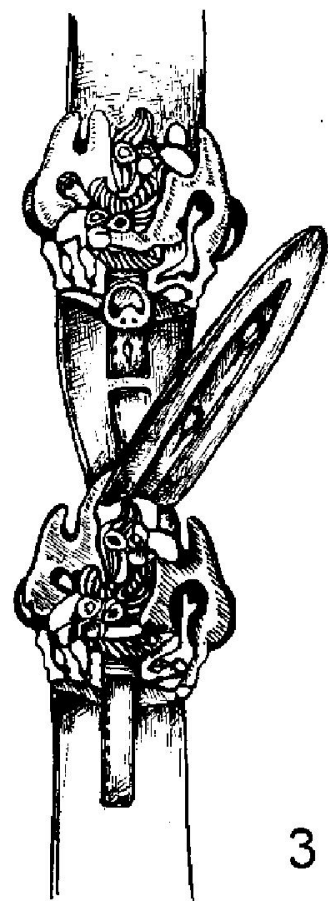

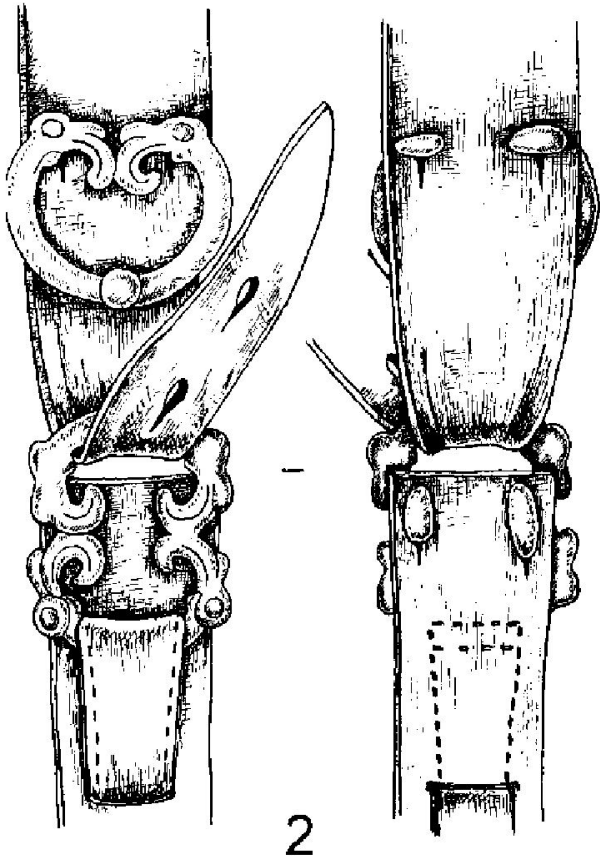

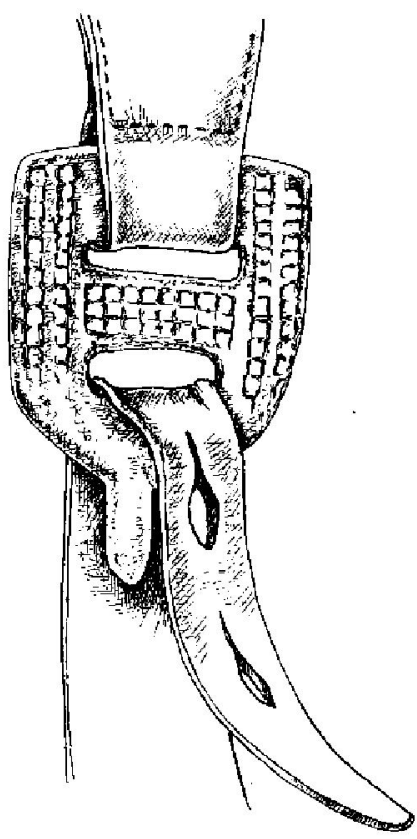

4

Рис. 2. Реконструкция системы застегивания подпружных застежек у кочевников Южного Приуралья в VI-IV вв. до н. э.: 1-3 - левые двухчастные подпружные застежки, бронза;

4 - левая одночастная подпружная застежка, кость.

1 - Кырык-Оба, курган 2; 2 - Три Мара, курган 3; 3 - Бесоба, курган 5; 4 - Филипповский I, курган 4 (рис. пряжек и петель по: 1- Гуцалов, 2011, рис. 1,16-18; 2 - Смирнов, 1981, рис. 4, 5-6; 3 - Кузнецова, Курманкулов, 1993, рис. 3, 11, 13; 4 - Яблонский, 2013, № 66) 
V.N. Myshkin. On Some Peculiarities of Using Girth Clasps by the Nomads

\section{ПРИМЕЧАНИЯ}

1 Работа выполнена в рамках государственного задания Министерства образования и науки РФ «Традиционные и инновационные модели развития древнего населения Поволжья».

2 Из выборки исключены небольшие кольцевидные или ромбовидные блоки с боковой прямоугольной, трапециевидной или округлой скобой. Вероятно, кочевники Южного Приуралья могли использовать их как подпружные застежки. Однако до настоящего времени в конских погребениях эти предметы пока встречены только около голов животных, что позволило интерпретировать их как чумбурные блоки [Очир-Горяева, 2012, с. 263, ил. 288; Мышкин, 2015].

${ }^{3}$ О принципиальной возможности использования ременных петель или деревянных застежек для фиксации седел свидетельствуют материалы из курганов пазырыкской культуры [Степанова, 2006, с. 115-116].

${ }^{4}$ В дальнейшем при характеристике материалов будут использоваться некоторые термины, применяемые в исследованиях как Е.В. Степановой, так и П.И. Шульги. В частности, ремень, закрепленный поверх и поперек седельных подушек, будет обозначаться как приструга [Степанова, 2005, c. 109] или как верхний подпружный ремень [Шульга, 2008, с. 34].

5 При подсчете не учитывались разрушенные комплексы или комплексы, по которым в публикациях отсутствуют точные данные.

\section{СПИСОК ЛИТЕРАТУРЫ}

Берлизов Н. Е. (2011). Ритмы Сарматии. Савроматосарматские племена Южной России в VII в. до н. э. - V в. н. э. Ч. І. Краснодар : КГУКИ : Парабеллум. 320 с.

Грязнов М. П. (1950). Первый Пазырыкский курган. Л. : Изд-во Гос. Эрмитажа. 92 с.

Гуцалов С. Ю. (2004а). Древние кочевники Южного Приуралья VII-I вв. до н. э. Уральск. 136 с.

Гуцалов С. Ю. (2004б). Ярусные погребения Южного Приуралья // Уфимский археологический вестник. Уфа: Гилем. Вып. 5. С. 135-152.

Гуцалов С. Ю. (2007). Кочевники Южного Приуралья в системе культур скифского времени Восточной Европы: общее и особенное // Региональные особенности раннесарматской культуры : материалы семинара Центра изучения истории и культуры сарматов. Волгоград : Изд-во ВолГУ. Вып. ІІ. С. 83-96.

Гуцалов С. Ю. (2009a). Погребение знатного кочевника скифского времени в урочище Илекшар (Южное Приуралье) // Российская археология. № 3. С. 72-78.
Гуцалов С. Ю. (2009б). Погребения скифской эпохи могильников Лебедевка II-III // Нижневолжский археологический вестник. Вып. 10. С. $306-324$.

Гуцалов С. Ю. (2010). Курганные сооружения могильника Кырык-Оба II в Западном Казахстане // Российская археология. № 2. С. 51-66.

Гуцалов С. Ю. (2011). Этнокультурная специфика могильника Кырык-Оба II в Западном Казахстане // Российская археология. № 1. С. 81-96.

Железчиков Б. Ф., Клепиков В. М., Сергацков И. В. (2006). Древности Лебедевки(VI-II вв. до н. э.). М. : Вост. лит. 159 с.

Кадырбаев М. К. (1984). Курганные некрополи верховьев р. Илек // Древности Евразии в скифосарматское время. М. : Наука. С. 84-107.

Кадырбаев М. К., Курманкулов Ж. (1976). Захоронения воинов савроматского времени на левобережье р. Илек // Прошлое Казахстана по археологическим источникам. Алма-Ата : Наука Казахской ССР. С. 137-156.

Кадырбаев М. К., Курманкулов Ж. (1977). Материалы раскопок могильника Бесоба // Археологические исследования в Отраре. Алма-Ата : Наука Казахской ССР. С. 103-115.

Кузнецова Э. Ф., Курманкулов Ж. К. (1993). Бронзовые изделия из памятников савроматской культуры Западного Казахстана (данные спектрального анализа) // Кочевники урало-казахстанских степей. Екатеринбург : УИФ Наука. C. $44-52$.

Моргунова Н. Л., Трунаева Т. Н. (1993). Раскопки кургана 2 могильника Покровка 2 в 1991 году // Курганы левобережного Илека. М. : ИА. C. $15-17$.

Мошкова М. Г. (1962). Ново-Кумакский курганный могильник близ г. Орска // Памятники скифосарматской культуры. МИА. М. : АН СССР. № 115. С. 204-241.

Мошкова М. Г. (1972). Савроматские памятники северо-восточного Оренбуржья // Памятники Южного Приуралья и Западной Сибири сарматского времени. МИА. М. : Наука. № 153. C. $49-78$.

Мышкин В. Н. (1993). Погребальный обряд кочевников Южного Приуралья VI-IV вв. до н. э. как исторический источник : автореф. дис. ... канд. ист. наук. М. 17 с.

Мышкин В. Н. (2012). Конь и сбруя в курганах кочевников скифского времени на Южном Урале // Уфимский археологический вестник. Уфа : ИИЯЛ УФЦ РАН. Вып. 12. С. 81-97.

Мышкин В. Н. (2015). Чумбурные блоки из кочевнических курганов скифского времени на Южном Урале // Известия СНЦ РАН. Самара : Изд-во СНЦ РАН. Т. 17. № 3 (2). С. 532-536. 
Очир-Горяева М. А. (1987). Погребальный обряд населения Нижнего Поволжья и Южного Приуралья VI-IV вв. до н. э. // Археологические исследования Калмыкии. Элиста. С. 35-53.

Очир-Горяева М. А. (2012). Древние всадники степей Евразии. М. : Таус. 472 с.

Пшеничнюк А. Х. (1983). Культура ранних кочевников Южного Урала. М. : Наука. 200 с.

Пшеничнюк А. Х. (2012). Филипповка: Некрополь кочевой знати IV века до н. э. на Южном Урале. Уфа : ИИЯЛ УНЦ РАН. 280 с.

Руденко С. И. (1960). Культура населения Центрального Алтая в скифское время. М. ; Л. : Изд-во Акад. наук СССР. 359 с.

Савельев Н. С. (2000). Курганы Баишевской долины в контексте культурогенеза ранних кочевников Южного Урала // Раннесарматская культура: формирование, развитие, хронология : материалы IV Международной конференции «Проблемы сарматской археологии и истории». Самара : Изд-во СНЦ РАН. С. 41-52.

Сдыков М. Н., Демкин В. А., Бисембаев А. А., Гуцалов С. Ю., Алексеев А. О., Алексеева В. А., Борисов А. В., Ельцов М. В., Жусупкалиев Т. Т. (2007). Скифы Западного Казахстана. Алматы : Исламнур. 208 с.

Симоненко А. В. (2009). Сарматские всадники Северного Причерноморья. СПб. : Фак. филологии и искусств СПбГУ. 328 с.

Смирнов К. Ф.(1961). Вооружение савроматов // МИА. М. : Изд-во Акад. наук СССР. № 101. 168 с.

Смирнов К. Ф., Петренко В. Г. (1963). Савроматы Поволжья и Южного Приуралья // САИ. М. : ИАНСССР. ВЫп. Д1-9. 127 с.

Смирнов К. Ф. (1964). Савроматы. Ранняя история и культура сарматов. М. : Наука. 379 с.

Смирнов К. Ф. (1975). Сарматы на Илеке. М. : Наука. $176 \mathrm{c}$.

Смирнов К. Ф. (1977). Орские курганы ранних кочевников // Исследования по археологии Южного Урала. Уфа : ИИЯЛ БФ АН СССР. С. 3-51.

Смирнов К. Ф. (1981). Богатые захоронения и некоторые вопросы социальной жизни кочевников Южного Приуралья в скифское время // Материалы по хозяйству и общественному строю племен Южного Урала. Уфа : БФАН CCCP. C. $68-90$

Степанова Е. В. (2005). Эволюция подпружных застежек по материалам алтайских курганов скифского времени // Снаряжение кочевников Евразии : сб. науч. тр. / отв. ред. А. А. Тишкин. Барнаул : Изд-во Алт. ун-та. 248 с.

Степанова Е. В. (2006). Эволюция конского снаряжения и относительная хронология памятников пазырыкской культуры // Археологические вести. СПб. Вып. 13. С. 102-150.
Шульга П. И. (2008). Снаряжение верховой лошади и воинские пояса на Алтае. Ч. I : Раннескифское время. Барнаул : Азбука. 276 с.

Шульга П. И. (2013). Конское снаряжение ранних кочевников Минусинской котловины (по материалам Минусинского музея им. Н. М. Мартьянова). Новосибирск : Ин-т археологии и этнографии. 149 с.

Яблонский Л. Т. (2008). Новые раскопки Филипповского могильника и проблема формирования раннесарматской культуры Южного Приуралья // Ранние кочевники ВолгоУральского региона : материалы Междунар. науч. конф. «Ранние кочевники Южного Приуралья в свете новейших археологических открытий». Оренбург : Изд-во ОГПУ. C. $170-176$.

Яблонский Л. Т. (2013). Золото сарматских вождей. Элитный некрополь Флипповка I (по материалам раскопок 2004-2009 гг.) // Каталог коллекции. Кн. 1. М. : ИА РАН. 232 с.

\section{REFERENCES}

Berlizov N.E. (2011). The Rhythms of Sarmatia. Sauromato-Sarmatian tribes in South Russia in the $7^{\text {th }}$ century $B C-5^{\text {th }}$ century BC. Part I. Krasnodar, KGUKI, Parabellum. 320 p. (in Russian).

Gryaznov M.P. (1950). The first Pazyryk barrow. Leningrad, Izd-vo Gos. Ermitazha. 92 p. (in Russian).

Gutsalov S.Yu. (2004a). Ancient Nomads of the Southern Urals in $7^{\text {th }}-1^{\text {st }}$ Centuries BC. Uralsk. 136 p. (in Russian).

Gutsalov S.Yu. (2004b). Tiered burial of the Southern Urals. Ufa archaeological bulletin. Iss. 5. Ufa, Gilem, pp. 135-152. (in Russian).

Gutsalov S.Yu. (2007). The nomads of the Southern Urals in the system of cultures of the Scythian period in Eastern Europe: General and special. Regional features of Early-Sarmatian culture: materials of seminar of the Center for history and culture of Sarmatians. Iss. II. Volgograd, Izd-vo VolGU, pp. 83-96. (in Russian).

Gutsalov S.Yu. (2009a). Burial mound of Noble Nomad of the Scythian times in the natural boundary of Ilekshar (Southern Urals). Russian archaeology, no. 3, pp. 72-78. (in Russian).

Gutsalov S.Yu. (2009b). Burials of the Scythian Epoch of the Lebedevka burial mounds II-III. The Lower Volga archaeological bulletin, iss. 10, pp. 306-324. (in Russian).

Gutsalov S.Yu. (2010). Burial structures of burial mounds of Kyryk-Oba II in Western Kazakhstan. 
Russian archaeology, no. 2, pp. 51-66. (in Russian).

Gutsalov S.Yu. (2011). Ethnocultural specificity of the Kyryk-Oba II burial mound in the Western Kazakhstan. Russian archaeology, no. 1, pp. 8196. (in Russian).

Zhelezchikov B.F., Klepikov V.M., Sergatskov I.V. (2006). Antiquities of the Lebedevka ( $6^{\text {th }}-2^{\text {nd }}$ Centuries $B C$ ). Moscow, Vostochnaya literatura Publ. $159 \mathrm{p}$. (in Russian).

Kadyrbaev M.K. (1984). Barrow necropolises of upper river Ilek. Antiquities of Eurasia in the ScythianSarmatian time. Moscow, Nauka Publ., pp. 84107. (in Russian).

Kadyrbaev M.K., Kurmankulov Zh. (1976). Interments of warriors of Sauromatian time on the left bank of the Ilek river. The past of Kazakhstan according to the archaeological sources. AlmaAta, Nauka Kazakhskoy SSR, pp. 137-156. (in Russian).

Kadyrbaev M.K., Kurmankulov Zh. (1977). Materials of excavations from the Besoba burial mound. Archaeological research in the Otrar. AlmaAta, Nauka Kazakhskoy SSR, pp. 103-115. (in Russian).

Kuznetsova Eh.F., Kurmankulov Zh.K. (1993). Bronze ware of the monuments of Sauromatian culture of Western Kazakhstan (spectral analysis of the data). Nomads of Ural-Kazakhstan steppes. Ekaterinburg, UIF Nauka Publ., pp. 44-52. (in Russian).

Morgunova N.L., Trunaeva T.N. (1993). Excavations of the mound 2 of Pokrovka 2 burial ground in 1991. Barrows of the left bank of Ilek river. Moscow, IA Publ., pp. 15-17. (in Russian).

Moshkova M.G. (1962). Novo-Kumanskii burial mound near the city of Orsk. Monuments of the Scythian-Sarmatian culture. Materials and Investigations on Archeology of the USSR. Moscow, AN SSSR Publ., no. 115, pp. 204-241. (in Russian).

Moshkova M.G. (1972). Sauromatian Monuments of North-East Orenburg Region. Monuments of the Southern Urals and Western Siberia of Sarmatian Times. Materials and Investigations on Archeology of the USSR. Moscow, Nauka Publ., no. 153, pp. 49-78. (in Russian).

Myshkin V.N. (1993). The funeral ceremony of Nomads of the southern Urals $6^{\text {th }}-4^{\text {th }}$ centuries BC as a historical source. Cand. hist. sci. abs. diss. Moscow. 17 p. (in Russian).

Myshkin V.N. (2012). Horse and harness in the mounds of the nomads of the Scythian period in the Southern Urals. Ufa archaeological bulletin. Ufa, IIYAL UFC RAN Publ., iss. 12, pp. 81-97. (in Russian).
Myshkin V.N. (2015). Culburnie blocks from nomadic burial mounds of the Scythian period in the Southern Urals. Proceedings of the Samara scientific center of the Russian Academy of Sciences. Samara, Izd-vo SNC RAN, vol. 17, no. 3 (2), pp. 532-536. (in Russian).

Ochir-Goryaeva M.A. (1987). The Funeral rite of the population of the Lower Volga region and the Southern Urals in $6^{\text {th }}-4^{\text {th }}$ Centuries BC. Archaeological studies of Kalmykia. Elista, pp. 35-53. (in Russian).

Ochir-Goryaeva M.A. (2012). The ancient horsemen of the steppes of Eurasia. Moscow, Taus Publ. 472 p. (in Russian).

Pshenichnyuk A.Kh. (1983). Culture of the Early Nomads of the Southern Urals. Moscow, Nauka Publ. 200 p. (in Russian).

PshenichnyukA.Kh. (2012). Filippovka: the nomadic elite Necropolis of the $4^{\text {th }}$ century $B C$ in the Southern Urals. Ufa, IIYAL UNC RAN. 280 p. (in Russian).

Rudenko S.I. (1960). Culture of the population of the Central Altai in Scythian time. Moscow; Leningrad, Izd-vo Akademii nauk SSSR. 359 p. (in Russian).

Savelyev N.S. (2000). Mounds of th Baishevskoe valley in the context of the cultural genesis of the Early Nomads of the Southern Urals. Early Sarmatian culture: formation, development and chronology. Proceedings of the $4^{\text {th }}$ international conference "Problems of Sarmatian archaeology and history”. Samara, Izd-vo SNC RAN, pp. 4152. (in Russian).

SdykovM.N., Demkin V.A., BisembaevA.A., GutsalovS.Yu., Alekseev A.O., Alekseeva V.A., Borisov A.V., Eltsov M.V., Zhusupkaliev T.T. (2007). Scythians in Western Kazakhstan. Almaty, Islamnur Publ. 208 p. (in Russian).

Simonenko A.V. (2009). Sarmatian horsemen of Northern Black Sea coast. Saint Petersburg, Fakultet filologii i iskusstv SPbGU, NestorIstoriya Publ. 328 p. (in Russian).

Smirnov K.F. (1961). Armament of Sauromatians. MIA. Materials and investigations on archeology of the USSR. Moscow, Akademiya nauk SSSR Publ., no. 101. 168 p. (in Russian).

Smirnov K.F., Petrenko V.G. (1963). Sauromatians of the Volga region and southern Urals. Collection of archaeological sources. Moscow, IAN SSSR, vol. D1-9. 127 p. (in Russian).

Smirnov K.F. (1964). Sauromatians. Early history and culture of Sarmatians. Moscow, Nauka Publ. 379 p. (in Russian).

Smirnov K.F. (1975). Sarmatians on Ilek. Moscow, Nauka Publ. 175 p. (in Russian).

Smirnov K.F. (1977). Orskaya barrows of the Early Nomads. Research on archaeology of the 
В.Н. Мышкин. О некоторых особенностях использования подпружных застежек кочевниками

Southern Urals. Ufa, IIYALBF AN SSSR, pp. 351. (in Russian).

Smirnov K.F. (1981). Rich burials and some of the issues of the social life of the Nomads of the Southern Urals in the Scythian time. The materials on the economy and social order of the tribes of the Southern Urals. Ufa, BFAN SSSR, pp. 68-90. (in Russian).

Stepanova E.V. (2005). Evolution of spring-loaded fasteners on materials of the Altai barrows of the Scythian period. Equipment of the nomads of Eurasia: collection of scientific papers. Barnaul, Izd-vo Alt. un-ta. 248 p. (in Russian).

Stepanova E.V. (2006). Evolution of horse equipment and relative chronology of the monuments of the Pazyryk culture. Archaeological news. Saint Petersburg, iss. 13, pp. 102-150. (in Russian).

Shulga P.I. (2008). The equipment of a riding horse and a military zone in the Altai. Part I: the early
Scythian time. Barnaul, Azbuka Publ. 276 p. (in Russian).

Shulga P.I. (2013). Horse gear of the early nomads of the Minusinsk basin (materials of the Minusinsk Museum N.M. Martyanova). Novosibirsk, In-t arkheologii i etnografii Publ. 149 p. (in Russian).

Yablonskiy L.T. (2008). New excavations in the Filippovsky burial and the problem of formation of early Sarmatian culture of the Southern Urals. Early nomads of the Volga-Ural region: materials of international scientific conference "Early nomads of the southern Urals in the light of recent archaeological discoveries". Orenburg, Izd-vo OGPU, pp. 170-176. (in Russian).

Yablonskiy L.T. (2013). Gold Sarmatian chiefs. Elite necropolis Filippovka I (on materials of excavations 2004-2009). Catalogue of the collection. Book 1. Moscow, IA RAN. 232 p. (in Russian).

\section{Information about the Author}

Vladimir N. Myshkin, Candidate of Sciences (History), Head of Archeological Laboratory, Samara State University of Social Sciences and Education, Leninskaya St., 127, 443041 Samara, Russian Federation, vnm59@bk.ru.

\section{Информация об авторе}

Владимир Николаевич Мышкин, кандидат исторических наук, заведующий археологической лабораторией, Самарский государственный социально-педагогический университет, ул. Ленинская, 127, 443041 г. Самара, Российская Федерация, vnm59@bk.ru.

Citation. Myshkin V.N. (2016). On Some Peculiarities of Using Girth Clasps by the Nomads of the South Ural Area at Scythian Time. The Lower Volga Arhaeological Bulletin, vol. 15, no. 1, pp. 4-21. (in Russian). 